This is the peer reviewed version of the following article: Sugden, F. and Punch, S. (2014), Capitalist Expansion and the Decline of Common Property Ecosystems in China, Vietnam and India. Development and Change, 45: 656-684, which has been published in final form at https://doi.org/10.1111/dech.12103. This article may be used for non-commercial purposes in accordance With Wiley Terms and Conditions for self-archiving. 


\title{
CAPITALIST EXPANSION AND THE DECLINE OF COMMON PROPERTY ECOSYSTEMS IN CHINA, VIETNAM AND INDIA
}

\author{
Fraser Sugden and Samantha Punch
}

\begin{abstract}
This article identifies some of the multiple processes of capitalist development through which access to common property resources and their utility for communities are undermined. Three sites in upland Asia demonstrate how patterns of exclusion are mediated by the unique and selective trajectories through which capital expands, resulting in a decline of common property ecosystems. The process is mediated by economic stress, ecological degradation and political processes such as state-sanctioned enclosure. The first case study from Shaoguan, South China indicates how rapid capitalist industrialization has depleted the aquatic resource base, undermining the livelihoods of fishing households yet to be absorbed into the urban working class. At the second site, in Phu Yen, Vietnam, capitalist development is limited. However, indirect articulations between capitalism on the lowlands and the peasant economy of the uplands is driving the commercialization of agriculture and fishing and undermining the utility of communal river and lake ecosystems. In the third site, Buxa in West Bengal, India, there is only selective capitalist development, but patterns of resource extraction established during the colonial period and contemporary neoliberal 'conservation' agendas have directly excluded communities from forest resources. Restrictions on access oblige them to contribute subsidised labour to local enterprises. The article thus shows how communities which are differentially integrated into the global economy are excluded from natural resources through complex means.
\end{abstract}




\section{INTRODUCTION: MECHANISMS OF EXCLUSION FROM COMMON PROPERTY RESOURCES}

Land-poor and marginalized households are disproportionately dependent upon common property resources (CPRs) such as forests, reservoirs or rivers to supplement fragile livelihoods (Agarwal, 1998; Beck and Ghosh, 2000; Dey, 1997; Luttrell, 2006). In the context of neoliberal globalization and unprecedented capitalist expansion into peripheral regions, there is a trend whereby the utilization of common property resources by marginalized groups is being increasingly constrained on economic, ecological and political levels. This has occurred through competition with large-scale industrial users of resources with associated ecosystem degradation (Agarwal, 1998; Ho, 2006; Sikor and O'Rourke, 1996); and through degradation by users themselves for multiple reasons including livelihood insecurity (Blaikie and Brookfield, 1987), or the demands of a market economy combined with the undermining of customary management systems (Hoàng, 2011; Sikor, 2002).

Access is also constrained through political mechanisms whereby management regimes exclude marginal users in order to pursue a commercial or 'conservation' agenda. Exclusion can emerge for example, through unequal power relations in planning which culminate in reduced access rights amongst marginal users (Cleaver, 1999, 2001; Platteau and Abraham, 2002); or the wholesale 'privatization', sometimes termed 'enclosure', of common property resources (Dey, 1997; Harvey, 2003; Hue, 2008; Hue and Scott, 2007; Parayil and Tong, 1998). More recently, Hall et al. (2011), focusing more specifically on land (both common and private), identify a more complex range of political power relations through which communities in Southeast Asia are excluded from natural resources under capitalist globalization. These include legislative frameworks or access rules, direct coercion, and the market forces of capitalism itself, such as the price mechanism. All of these processes are supported by a set of legitimating ideologies, often of the state.

This article builds upon the above literature to uncover the diverse processes associated with capitalist globalization through which communities are excluded from natural resources, with a focus on those which are common property. However, specific links are drawn with the unique trajectories of capitalist growth in peripheral regions. There is a tendency for scholarship to focus on the unprecedented expansion of capitalism under globalization, 
signalling an almost inevitable dissolution to pre-capitalist social relations (Sugden, 2013). Contemporary scholarship in the field of agrarian change has demonstrated, for example, how state cut-backs in peripheral economies under neoliberalism and growing export-oriented sub-sectors intensifies differentiation within the peasantry, a pre-cursor to capitalist development (Akram-Lodhi, 2007, 2008; Bernstein, 2003; Oya, 2001). Some studies even suggest that the drive by capital from more developed regions to locate 'super-profits' requires differentiation by extra-economic means (Akram-Lodhi, 2007; Harvey, 2003; Patnaik, 2007). In the contemporary periphery, this is characterized by the appropriation of land for capitalist investment, often with the support of foreign capital (Harvey, 2003). ${ }^{1}$

This article seeks to demonstrate that capitalist expansion can be more selective, and that it does not necessarily 'dissolve' older economic formations. The latter can persist, yet also articulate with capitalism. The article illustrates the complexity of the contexts in which the rural poor are excluded from common property resources under neoliberal globalization, with processes including ecological pressure, economic stress and unequal political power relations, including state-sanctioned enclosure. Most significantly, the ways in which these processes are constituted is itself shown to be linked to the selective expansion of capitalism and persistence of older economic formations.

A central tenet of the Althusserian tradition of political economy was to identify historical individualities of given social formations rather than attempting to fit what is observed into a pre-ordained evolutionary framework, in this case driven by a vision of an all-powerful, allencompassing capitalism. The underlying dynamics of social transformation can only be uncovered through the historical analysis of empirical data for geographically and historically specific conjunctures (Raatgever, 1985). A body of literature from sub-Saharan Africa has shown how the diversity of pre-capitalist economic formations can lead to considerable variation in the trajectories of change which arise from contact with the market (Dupré and Rey, 1979; Geschiere and Raatgever, 1985; Meillassoux, 1973). This involves a complex interplay between not only economic but political and ideological processes. A key process identified by this scholarship is the articulation of modes of production (a term initially

\footnotetext{
${ }^{1}$ While some of these studies have pointed to a more complex pattern of change with 'petty commodity production' persisting to serve capitalism (Bernstein, 1977, 2003; de Janvry, 1981), these studies tend to imply that these older forms are functionally 'dependent' upon capitalism which is always the dominant force (see Sugden, 2013).
} 
coined by Althusser and Balibar, 1968), whereby capitalism co-exists and articulates with older economic formations. The internal structure of the older mode of production may allow it to maintain relative autonomy, even while supplying labour or commodities to capitalism.

This article uses elements of this approach, yet considers how these diverse processes of capitalist expansion mediate ecological change and acess to natural resources. Furthermore, whilst recognizing the selective trajectories of capitalist development, it does also show that market-led globalization has invariably led to a decline in common property ecosystems for marginalized communities. The character of this decline is shaped by the unique mechanisms through which capital expands into localities. The term 'common property resources/ecosystems', as used in this article, refers to ecosystems not owned by individual households or enterprises, which allow a set of users full or partial access to exploit natural resources without payment (Wade, 1987). This should be distinguished from 'open access resources', where there are no pre-defined set of users or rules (Dasgupta, 2008; Ostrom, 1990). However, the line between the two is not clear cut, and the degree to which the ecosystems described here are 'regulated', either formally or informally, is variable.

The article begins by outlining the methods and political-economic contexts of the study sites and goes on to identify the shifting interactions between communities and their environments in the context of economic change.

\section{Site Selection and Methods}

The research on which this article is based was part of a multi-partner, multi-disciplinary European Commission funded project which analysed aquatic resource use and associated conservation and management dilemmas in five upland watersheds of China, Vietnam and India. The three case studies chosen for this paper have comparative histories, whereby over the last three centuries, coercive state formations have gradually increased their control over land and natural resources, shaping the trajectory of livelihoods and nature-society interactions. However, during the twentieth century, capitalism has achieved quite different levels of dominance. Shaoguan district of South China is a region with a rapidly advancing industrial economy. Phu Yen district in northern Vietnam is a remote region with only small- 
scale proto-capitalist development on the valley floor alongside the Song Da reservoir. Buxa in India's West Bengal lies in the foothills of the Bhutan Himalaya and was long a frontier region where livelihoods depended entirely upon forest and river resources, although it has a more recent history of colonial resource extraction.

The livelihoods element of this project included a combination of qualitative and quantitative techniques in a process of triangulation in line with the project's interdisciplinary agenda (see www.higharcs.org). At each field site a sample of three rural villages were chosen. Field sites and villages were selected by in-country teams on the basis that they were dependent on the same aquatic ecosystem (i.e. river basin) and were located in upland regions. Using a wealth ranking exercise in consultation with local leaders and key respondents, a stratified sample of thirty households in each village were selected for an in-depth survey, totalling ninety households (thirty poor, thirty medium and thirty rich). Quantitative data was collected on livelihood activities, sources of income and asset ownership, followed by more open-ended questions. To gain deeper qualitative insights, focus groups were conducted: ten groups each of men, women, girls and boys, totalling forty at each site. Participatory techniques were used, including community resource mapping, production of historical and annual timelines, and livelihood ranking activities. The quantitative data was analysed using SPSS and a thematic analysis was conducted for the qualitative data.

\section{BACKGROUND TO LIVELIHOODS AND PROCESSES OF CAPITALIST EXPANSION}

\section{Shaoguan, China}

Shaoguan, a prefecture-level city with a large rural hinterland, lies in Guangdong province in South China. The focus of the study was on three villages that traditionally depend on fishing along the Beijiang river. Lishi village is at the lower end of the Wujiang River, Kengkou is located on the Beijiang River downstream from Shaoguan city, and Zhoutian is upstream (see Figure 1). One common historical process which has been present in all three field sites has 
been a pattern of feudal subordination ${ }^{2}$ long before the emergence of socialist or capitalist economic formations. Although it is impossible to generalize a complex, regionally diverse history, up until the mid-twentieth century, the rural economy in China has often been considered feudal in character (see Schwartz, 1954). While private property rights to land were relatively well developed by the eighteenth century, and there was an independent peasantry, large landlords had significant class power and, alongside a powerful state apparatus, appropriated much of the surplus (Feuerwerker, 1984). Through their income from landlordism, the bureaucracy, money lending and commerce, they were able to increase their wealth and buy up the private plots of individual peasants (Schwartz, 1954). ${ }^{3}$

\section{[Figure 1 about here]}

Guangdong was one of the more developed provinces from the eighteenth century onwards (Buoye, 1993). There was a burgeoning commercial sector with an expanding market for land and commodities, inter-provincial trade and production of commercial crops. Nevertheless, persisting landlordism combined with population growth led to critical land shortages and growing disputes between and within the tenant and landlord class (ibid.). This offers some background to the oral histories of the fishers in the Beijiang watershed. The ancestors of the fishers of Zhoutian reported that around two centuries ago, they had been tobacco farmers in Shixing county. Due to increasing population and limited land, they migrated to the banks of the upper Beijiang river to work as labourers in the river transport sector. In the past rivers were crucial routes for the transport of commodities, and large boats would be pulled upstream by groups of labourers using ropes. This provided employment to the farmers from Shixing. However, when they started families they could not support themselves with their meagre earnings, and became dependent upon fish from the Beijiang river (household interview, Zhoutian, July 2010). ${ }^{4}$

\footnotetext{
${ }^{2}$ The predominant attributes of feudalism alluded to by Marx (1932) include control over land by a minority class with political and ideological as well as economic power over a peasant majority and appropriation of surplus in kind by rent or usury, often through extra-economic means.

${ }^{3}$ In the early twentieth century, prior to the Communist victory, Brandt and Sands (1990) estimate that up to a third of land was not owned by peasants but rented.

${ }^{4}$ In Lishi and Kengkou villages, the history is less clear, although it was reported that the population of both villages migrated to their present location around two centuries ago from Heyuan city (household interview, Lishi, July 2010).
} 
The Communist revolution spurred a dramatic structural transformation. Agriculture as well as livelihood activities dependent upon common property resources such as fishing were transformed according to socialist principles, with fishing cooperatives established in 1958 (Liu et al., 2011). Households would sell fish to the cooperative and receive payment from the government.

It was only during the 1980 s that capitalist industrialization emerged from within the socialist system. Fishing and agriculture were decollectivized, and fields were distributed in a largely egalitarian manner under a lease system (Eyferth et al., 2003; Luong and Unger, 1998). Whilst providing new opportunities for individual generation of wealth, differentiation inevitably increased (Luong and Unger, 1998). Although fishing offered few possibilities for accumulation, it was reported that up until the 1990s fish stocks were abundant. The river could provide a relatively comfortable subsistence. Many fishers diversified their livelihoods by working in small-scale industries, many of which had previously operated as collectives.

Throughout the 1990s and 2000s, rapid capitalist industrial development ensued across China, bolstered by a strong state apparatus. Provinces such as Guangdong were lead players in the new Chinese economy, and Shaoguan (both the urban area and surrounding counties) experienced rapid industrialization. In 1978 the secondary (manufacturing) sector in Shaoguan was worth just Rmb 464,000; by 2008 it was worth a staggering Rmb 26.256 billion (Luo et al., 2011).

Today, fishing continues as a key livelihood activity for many households in Lishi, Kengkou and Zhoutian. However, there is negligible 'capitalist' differentiation within these communities, and most fishers can be considered a single 'class' in the Marxian sense. There are differences in wealth with some households better endowed than others with regards to nets and equipment. However, the household survey shows that fishing is not a source of 'accumulation' and fishing incomes have declined significantly since the 1990s. The only two households displaying capitalist tendencies and employing labour had diversified into new sectors, one operating a commercial pig and fish farm and the other a shoe business. The younger generation today are being drawn into an expanding class of capitalist labourers. Fishing is now a supplementary source of income, eclipsed by income from work in factories both locally and in nearby cities (see Figure 2). Household members are thus engaged in a 
pre-capitalist economic formation based upon subsistence fisheries which is in rapid decline, while simultaneously labouring in the capitalist sector.

[Figure 2 about here]

\section{Phu Yen, Vietnam}

In the district of Phu Yen, in the west of Son La province, three villages in the two communes of Tuong Ha and Tuong Tien were selected for the research (see Figure 3). The valley is culturally diverse, with a predominant population of the Muong and Thai minority on the lower slopes and valley floor, while smaller H'mong communities reside in villages on the higher slopes.

\section{[Figure 3 about here]}

Unlike Shaoguan, the minorities of remote Son La province were historically at the margins of state control, particularly in the pre-colonial period. Sets of villages or muangs operated as relatively autonomous units ruled over by a phiia or chief (Hoàng, 2011; Sikor, 2001b). All land could be considered the common property of the muang, although there was a complex management regime with the level of regulation varying according to the land type. Hoàng's (2011) study of the Thai communities in the Phu Yen valley notes that the most important wet rice land was controlled by the community, with plots being allocated for a period of time according to household need. Upland fields for shifting cultivation could be claimed from the forest and households maintained the right to collect forest products; thus the rules for exploiting these resources were more open, so long as one was not from outside the muang. Although land was held communally, Hoàng's study from Phu Yen and Sikor's (2004) from nearby Yen Chau district, show that hierarchies still existed. The phiia was considered the symbolic owner, with control over production process including the allocation of plots of paddy land, rights to collect a share of paddy as tax before it was distributed, and rights to personal plots of the best land. 
The onset of French colonialism, rather than implanting capitalism, served to reinforce precapitalist inequalities (Dao, 1993). For example, in neighbouring Yen Chau, Sikor (2004) notes how the French demanded large taxes and corvée labour contributions from the Black Thai leaders, a burden which was passed on to the peasantry. This parallels oral histories in Tuong $\mathrm{Ha}$ and Tuong Tien. One elder Thai respondent in the research recalled that after planting rice, corn and cassava, local people were obliged to give a share as tax directly to local leaders. These intermediary tax collectors became de facto land owners, channelling revenue to the French colonial regime while retaining a portion for personal use, and employing their poorer counterparts as sharecroppers (household interview, Tuong Tien, April 2010).

Following independence from the French in the 1950s, the new communist government pursued land redistribution from large landlords to landless peasants (Kerkvliet, 2006; Sikor and Truong, 2002). This was followed by a policy of collectivization, whereby land, labour and other resources were shared (Sikor, 2001a), once again as a highly regulated common property regime. Wet rice lands were administered by the newly created communes, and as in China, households worked together for points according to labour hours, which were converted into shares of food and money. Households continued to independently farm cassava and other crops on the wooded upper slopes as in the past, although state regulations increasingly sought to limit the size of fields and discourage shifting cultivation (fieldnotes, April 2010). Sikor (2004) notes, however, that regulations for the use of upland forest land in the northern highlands were not strongly enforced, particularly as forests were placed under state control, undermining traditional management institutions (Hoàng, 2011). Nevertheless, Folving and Christensen (2007), in a study from two nearby communes in Phu Yen, suggested that there were well-defined systems of customary tenure within the community that determined which land could be cleared by families. Respondents in Tuong Ha commented that extensive tracts of forest land remained intact during the communist period, suggesting the uplands were managed sustainably. It therefore could not be considered as 'open access'.

From the 1980s, external interventions by the state prompted considerable transformations to the livelihoods of the valley. Between 1986 and 1989 households moved to higher ground to make way for a new reservoir which would flood the valley following the construction of the 
Soviet-funded Hoa Binh dam downstream. A large portion of the most fertile rice land was permanently lost under water, while some land was now flooded seasonally, allowing just one rice harvest. This reservoir however, represented a new common property ecosystem, and fishing activities were increasingly promoted and supported through the government's Project 747 (Do et al., 2011). By the late 1980s, economic problems facing the cooperative farms, combined with a growing influence of neoliberalism, led to a government policy of liberalization or doi moi, literally 'renovation' (Hue, 2008). This resulted in the decollectivization of agriculture, which finally paved the way for capitalist penetration.

While capitalist agricultural development and industrialization accelerated in lowland Vietnam, with differentiation and intensified class inequalities (Akram-Lodhi, 2005; Hue and Scott, 2007), the character of capitalist expansion was more selective in the isolated communities of Phu Yen. Although there were no large-scale capitalist farms or industries as in Shaoguan, small-scale cash crop production has developed, providing corn and cassava for sale in lowland urban centres. Income is also generated through the sale of reservoir resources and lowland traders visit the commune daily to collect shrimp to take to the plains. However, unlike in Shaoguan where fishers have no involvement in agriculture, the households in Phu Yen simultaneously fish in the reservoir, while producing commercial crops on upland fields and grain staples on lower slopes. Figure 4 shows that for the sampled households, income from fish and crop sales are on average the most important source of income. Although supplying produce to capitalist markets, the household remains the predominant unit of production, and pre-capitalist patterns of subsistence peasant farming persist alongside commercial activities.

[Figure 4 about here]

The root of these articulations between the peasant economy of the uplands and the capitalist markets of the lowlands evidently lies in growing cash demands and indebtedness associated with the liberalization process. Interviews revealed that in the collective era the communes were able to retain a degree of self-sufficiency. Following liberalization, however, cash needs had expanded considerably for various reasons. First, local people now had access to commodity markets as restrictions on inter-provincial trade were lifted as part of the liberalization process. Coupled with an expansion of the transport network, traders could now 
purchase agricultural produce to transport to the lowlands, while bringing in consumer goods (Sikor and Vi, 2005). In this context households displayed a desire to invest in luxury consumer goods such as televisions, fridges and mobile phones which are often beyond their usual purchasing power (see also Hoàng, 2011), as well as in expensive upgrades to houses (see Figure 5). Second, in the transition to a market economy, cash was now needed for social services which were once provided by the state such as education and healthcare (see Figure 5). The combination of easily available low-interest credit from microfinance banks and high expenditure has intensified cycles of indebtedness, to banks as well as to an emerging class of local money lenders. Third, prior to the building of the dam and the flooding of the valley, most households could meet their grain staple needs through rice farming but now families need cash to buy rice. The cumulative effect of growing cash needs is the expansion of cash crop production on upper slopes, and fishing.

[Figure 5 about here]

\section{Buxa, India}

Buxa is a forested region in the Dooars, the forest belt of West Bengal's Jalpaiguri district in Kalchini subdivision, where the Siwalik range of Himalayan foothills meets the plains. Today it is home to the Buxa Tiger Reserve, a protected region of rich forest and aquatic biodiversity. Three village clusters were the focus of the study: Buxa Fort consists of small settlements in the hills around a ruined colonial era fort; Adma is a remote set of hamlets in the valleys to the west; and Jayanti lies on the gentle alluvial slope where the hills meet the plains (see Figure 6).

[Figure 6 about here]

Phu Yen and Buxa share similar histories, both being frontier regions home to minority communities, with limited state influence. The predominant population of the Buxa plains was made of indigenous communities such as the Meche and Garo, while the hilly tract was home to Dukpa (the majority ethnic group in Bhutan) who were later joined by migrants from Nepali communities such as the Limbus and Magar (Grunning, 2007 [1911]). Across the 
North Bengal frontier, agriculture was characterized by shifting cultivation or jhum by the indigenous communities who lived in small settlements, led by a Mandal or headman (Ray, 2002). The uncultivated forest lands and rivers were extensive, and were largely common property rather than being owned by individual households (ibid.). Although there was limited centralized regulation of these resources, it would be wrong to term them 'open access', as indigenous communities may have had their own system of rules within localities.

As had occurred across South and Southeast Asia, the imposition of centralized state formations had a lasting impact on indigenous modes of production. One of the first significant states to emerge was that of Bhutan. When the entire Dooars region was annexed in the 1700s, Bhutan enforced its authority over forest-dwelling communities by requiring them to provide labour service as well as levying taxes on the use of irrigation channels, on plying boats, on weaving looms and on squatting in the jungle (Chaudhuri, 1995; Ray, 2002). In the lowlands, the Bhutanese encouraged settlement and land reclamation from the forest (Ray, 2002). Enterprising peasants from the south, or jotedars, were given incentives to clear the jungle and bring in tenants to farm under feudal relations (Chaudhuri, 1995). This process saw the slow contraction of the forest frontier, although much of the Buxa population remained scattered and free from state control, with livelihoods dominated by shifting cultivation (Grunning, 2007 [1911]). In this context, many forest resources informally remained as common property, even though land was being increasingly parcelled up amongst the new rulers.

After the Anglo-Bhutan war in 1846, the British colonial state annexed the Dooars from Bhutan, and by the late nineteenth century, the influence of capitalism had increased through the coercive mechanisms of the state. On the edge of Buxa forest in regions already under permanent cultivation, rather than seeking to impose capitalist social relations, the British formalized the existing hierarchy of jotedars and their tenants, the chukanidars and adhiyars (Ray, 2002). By preserving this hierarchy and the right to sub-let land, the clearing of forest could be accelerated, while the expansion of colonial control could be facilitated (Chaudhuri, 1995). While in Phu Yen, Vietnam, capitalism had a more limited impact on livelihoods during the colonial period, the British colonialists in Bengal recognized the potential of the resource-rich Dooars for commercial forestry and tea production, and by the late nineteenth century, finance capital expanded into the region as European companies set up plantations 
on the forest fringe (Ray, 2002). Paralleling trends across North Bengal and Assam, the British encouraged the migration of adivasi (indigenous) groups from central India to meet labour shortages (Grunning, 2007 [1911]).

Across the Dooars, many former forest-dwelling communities were now working as landless tenants for new jotedar settlers under semi-feudal relations of production (Chaudhuri, 1995; Ray, 2002), although within the Buxa jungle itself communities continued to follow indigenous livelihood patterns. However, the wooded area was shrinking with the expansion of new jotedar estates, tea cultivation, and indiscriminate felling by timber traders. The colonial state was increasingly concerned with securing strategically important timber supplies (Banerjee et al., 2010) for the expansion of railway networks and to supply boxes for the tea industry (Grunning, 2007 [1911]). It was in this context that new legislation had a lasting impact upon the remaining communities of forest dwellers.

The Forest Act, which forms the basis of contemporary legislation, was implemented in 1865 . The Act appointed a settlement officer to look into the 'claims' of users and decide which forests should be put under state control. Land in Jalpaiguri district was now classified into three categories: agricultural land, tea garden and reserved forest (Bhowmik, 1988). Colonial sources indicate that by 1879,280 square miles of country had been declared as reserved forest in Jalpaiguri district, encompassing much of the Buxa region (Grunning, 2007 [1911]). The Forest Act not only prohibited the expansion of cultivation in land classified as 'reserved forest', but it essentially gave the state legal backing to extinguish pre-existing informal rights of local people to forest resources with limited negotiation (Banerjee et al., 2010). The pre-existing rights included agricultural and livelihood activities such as shifting cultivation, hunting and the collection of firewood and non-timber forest products: these were now criminalized. State-run forestry enterprises were given monopoly over resource extraction operations and the sale of timber to the markets of Kolkata and Dhaka proved highly profitable ${ }^{5}$ (Grunning, 2007 [1911]).

The restrictions on access to forest lands meant forest dwellers could no longer meet their subsistence needs through agriculture. Forest enterprises had a valuable opportunity to exploit

\footnotetext{
${ }^{5}$ The net profit in Buxa division increased from Rs 6,093 in 1900-01 to Rs 99,673 by $1907-08$ (Grunning, 2007 [1911]).
} 
this destitution. 'Forest villages' were specifically set up to provide a labour force for forestry operations across Jalpaiguri district (Grunning, 2007 [1911]). Small plots of land were distributed to former jungle dwellers as well as migrants, who were expected to cultivate sal and teak monocultures alongside subsistence plots. In return for the right to reside in the forest they were obliged to provide un-waged labour or begar to the Forest Department's operations (Banerjee et al., 2010), in a bonded labour relationship. Jayanti was set up as one of these 'forest villages', and being at the foot of the mineral rich Siwalik hills, it was also home to a dolomite mine and processing factory. Nepali, Bengali and adivasi labourers from the surrounding estates and agricultural land were brought in to work in the mine, expanding the settlement's population. Despite the criminalization of forest-based livelihoods, most communities had no option but to continue to use the jungle for small-scale agriculture, collection of forest produce, herding and fishing in order to subsist. Paradoxically, these precapitalist livelihood activities ensured the reproduction of a cheap labour force for the forest villages. $^{6}$

The primary difference with Vietnam and China in the second half of the twentieth century was that the colonial economy of India essentially remained in place, despite the transition to home rule. There was no 'socialist' revolution. There was some emerging capitalist industry in urban centres, but in the Dooars, the primary sector-based colonial economy of tea production, forestry and mining coexisted with a pre-capitalist sector of small-scale peasant farming and older forest-based activities, which provided it with labour (see Sugden, 2010). Begar obligations were abolished in the 1960s following considerable agitation by forestdwelling communities (Banerjee et al., 2010). However, the Forest Department still restricted livelihoods, and households were obliged to provide low-wage labour to the Forest Department, the dolomite mine, and contractors involved in activities such as stone collecting on the Jayanti river. Use of the forest was tolerated by the state to a limited extent, as this was the only means through which labour could be reproduced and wages remain low.

Participation in the capitalist sector therefore was not through commercial agriculture and commoditization as in Phu Yen, but through the supply of low-wage labour, mediated by the coercive mechanisms of the colonial and post-colonial state. However, it is important to note

\footnotetext{
${ }^{6}$ In other words, some of the subsistence needs are met through pre-capitalist activities, allowing lower wages to be paid, a process noted in Sugden (2013).
} 
that as with Phu Yen, the older pre-capitalist livelihoods grounded in natural resource dependent activities persisted alongside wage labour. In this context, far from capitalism dissolving these older formations, it in part perpetuates them as they provide capitalism with a source of surplus.

\section{CAPITALIST INDUSTRIALIZATION, ENVIRONMENTAL DECLINE AND THE EXPANDING WORKING CLASS}

The following section considers how common property resource based livelihoods have fared under the different trajectories of capitalist expansion identified above, using the findings from the field research.

\section{Ecological Change through Rapid Capitalist Industrialization}

The first identified process through which common property resource based livelihoods are undermined is ecological change, whereby small-scale users come into competition with large-scale industrial users who deplete ecosystems or render them unusable. Inevitably, these phenomena are associated with regions undergoing rapid industrialization such as China and Vietnam. In China, for example, as well as experiencing large-scale deforestation, ${ }^{7}$ industrial and urban pollution has resulted in $25,000 \mathrm{~km}$ of rivers failing to meet the water quality standards necessary for aquatic life as of 2004, while irrigating land with polluted water is estimated to cost the economy Rmb 7 billion a year (World Bank and SEPA, 2007). Industrial development and large-scale commercial agriculture and fisheries production have also undermined ecosystems in parts of Vietnam (Sikor and O'Rourke, 1996). However, in this study, given the relative isolation of Phu Yen, it is in Shaoguan, China that these processes are most visible. In fact, the Shaoguan fishers' gradual assimilation into the working class is closely linked with growing competition with industrial users of the Beijiang river (Liu et al., 2011).

\footnotetext{
${ }^{7}$ Forest cover was found to have decreased by 4.54 million hectares between the 1984-88 and 198993 inventories, and by a further 1.23 million hectares by 1994-1998 (Ho, 2006).
} 
The river remains a common property resource allowing fishing without payment. There are a series of constantly evolving government programmes to regulate the use of water resources in the basin (so it cannot be considered 'open access'), although laws regulating the activities of fishers have only a limited impact on fishers' livelihoods. The licensing system stipulates the number of boats and engine sizes, but there are no regulations on the types of fishing equipment, and fishing without a licence is tolerated (Jiang et al., 2011). The fishers' use of this common property ecosystem therefore has not been undermined through direct exclusion or 'enclosure', but as a result of the gradual, yet severe, degradation of the natural resource base.

The annual fish harvest from the Beijiang river reached 8,000 tons in the 1950s, including many high-value and rare local species. Since 2000, however, annual fishing production has not exceeded 2,000 tons, and most fish caught are lower-value species (Jiang et al., 2011). The degradation of the river ecosystem is closely connected with unprecedented industrial expansion. First, sand mining, which was mechanized in the mid-1990s, has mushroomed, providing materials for the burgeoning urban construction sector. It has changed the structure of the river bed, and has influenced the hydrological regime and sand silt characteristics. Some river banks have collapsed, the water level has dropped markedly in some locations, blocking the movement of boats, while other channels have become narrow (Han et al., 2005; Qian, 2004). It has also influenced nutrient cycling and has altered the ecosystem of fish. In Zhoutian, for example, the fishers noted it had caused a decline in water grasses, impacting fish breeding.

Second, water pollution has caused the biological accumulation of toxic material across the food chain. In the past, the fishers reported that they used to swim in the river, but now it would cause them to fall sick. Some respondents stated that fish had a diesel oil taste, lowering their value. Sources of pollution include effluent from industries, such as the iron mine near Kengkou village, and diesel leakage from transport barges or sand mining boats, not to mention urban waste. Respondents noted that growing urban prosperity has meant people buy many more manufactured products, the packaging of which can end up in the river. 
Finally, hydropower developments have had a significant impact on fish stocks. The utilizable hydropower in the Beijiang watershed reaches $1,474,000 \mathrm{~kW}$ and there are 1,989 small-scale hydropower stations (Jiang et al., 2011). The construction of dams, both large and small, has changed the ecological structure, such as the hydrology, water quality, sediment levels and quantities of aquatic organisms. Furthermore, dams limit the migration of fish, and when the dam is opened, many fish are lost by being washed downstream. On an economic level, the deeper water means fishers have had to change their nets, and the dam's location restricts where they can take their boats.

Management regimes for industries do exist, including pollution discharge fees and water environment standards and monitoring (Jiang et al., 2011). Furthermore, pollutant discharging enterprises are supposed to be strictly controlled in terms of the quality, concentration and volume of waste which is released into rivers. Nevertheless, analysis with stakeholders suggest that laws are poorly implemented, a reminder that there is no clear cut difference between regulated 'common property' and 'open access' resources. For example, despite sharing authority in water governance, there is limited coordination for monitoring between different government agencies involved with the environment, construction, agriculture, geology and mining, fisheries and shipping. This allows some enterprises to bypass regulations, whilst impeding the introduction of new rules. The Shaoguan Fisheries Agency, for instance, consulted hydropower dams on the feasibility of charging them fishery resources compensation tax in 2004 and 2006, but due to the lack of authorization from formal legislation, the agency did not have the power to follow this up. There is also a lack of coordination between different administrative zones, and the legal responsibility of upstream enterprises whose pollution affects downstream regions remains unclear. Many rules are perceived as ambiguous, and legal loopholes have allowed some dams in the Shaoguan district to bypass the need to perform an Environmental Impact Assessment (Jiang et al., 2011).

A further factor, and perhaps the most significant, is the issue of power relations associated with capitalist expansion and the mediating role of the state. There was a strong perception within the fishing communities that corporations had the power to avoid regulations, or that they were of such economic importance that the state turned a blind eye. With sand mining in particular - arguably the most destructive use of the river - we discussed options for more 
effective regulations with fishers. However, respondents dismissed our ideas, believing it would be impossible to control the mining activities. They felt the root cause of this problem was that local government leaders are only in office for four years, so they concentrate on maximizing short-term economic growth, even though they know that sand mining is destructive.

Interestingly, farmers reportedly received compensation from sand mining companies due to the damage to river banks adjacent to villages, while fishers received nothing. Luong and Unger (1998) suggest that in the post-reform period, an important axis of differentiation alongside one's access to capital, is one's political authority, or position in the 'bureaucratic rank order'. Well-connected peasant households are able to build up effective patronage networks with local officials, offering opportunities for wealth accumulation (Luong and Unger, 1998; Yan, 1992). The farming population is not only significant, but also forms an important lobby group. Fishers recalled in interviews that if farmers had not received compensation from the sand miners, they would probably have put pressure on the state to control their activities. In contrast, fishing communities tend to have little involvement in politics and they do not have any formal representation as a community. The lack of political power in the hands of fishers perhaps partially explains why their alienation from the means of production (the river) and absorption into the urban working class is proceeding at a much faster pace than that of their farmer counterparts.

In sum, ecological decline and unequal political power relations in the management of river resources has meant that fishing is no longer sufficient to meet households' subsistence needs. As Figure 2 suggests, households are increasingly dependent upon the labouring income provided by sons and daughters. The closure of smaller local enterprises in recent years, with the rise of larger-scale factories in cities, means that migration for work is increasing (fieldnotes, July 2010). Payment for factory work is around Rmb 1,000-1,200 (US\$ 152-181) per month for a 9-10 hour day (household interview, Lishi, August 2010). Most concurred that it was difficult to support a nuclear family on this income in urban China, let alone the extended family. Therefore, despite falling catches and destruction of the ecosystem, fishing remains a crucial source of subsistence for the older generation, particularly given the limited welfare provision under a liberalized economy. There are also limited opportunities for the older generation to join the urban labour force (Sugden and Punch, 2013). Some perceive they lack the necessary skills: 'We are old and do not know 
anything, nobody need us [in the city]' (men's focus group, Kengkou, August 2010). Whilst today small-scale fishing, a remnant of an older pre-capitalist economic formation, 'subsidizes' the labour of the urban capitalist economy by providing for the older generation, the future prospects for this livelihood activity remain limited.

\section{Commercialization of Peasant Production and Environmental Decline}

Whilst fishers in Shaoguan face environmental decline from rapid industrialization, in regions lacking significant capitalist development, degradation and ecological change can be due to over-use by small-scale users themselves. In upland regions of Vietnam this phenomena still has an intricate association with the dynamics of capitalist expansion, as older economic formations - under stress from economic liberalization and growing cash needs - articulate with capitalism through unsustainable patterns of cash crop production and fishing. At the same time, growing inequalities in a market economy often oblige land-poor households to intensify the extraction of natural resources (Sikor, 2002, 2004).

In the case study from Phu Yen, the expansion of cash crop production under the pressures of a market economy has led to a significant reduction in the size of forest ecosystems which were once the common property of communities (Do et al., 2011). This parallels trends across Vietnam. Between 2000 and 2005, the coverage of primary forest across the country declined by 14.59 per cent, at the rate of 20,000 ha per year. Between 2005 and 2010 this had levelled off, yet forest cover still declined by 1.21 per cent in this period (FAO, 2010). ${ }^{8}$ Although the land allocation acts of the 1990s delineated ownership to fixed private upland fields on the forested slopes in Tuong Ha, demarcation was reportedly poorly enforced. The demand for cash which had driven the expansion of corn production led to a significant increase in the cultivated area in the years following decollectivization as households 'claimed' fields from the forest as private holdings (focus groups, Tuong Ha, March 2010). Hoàng (2011) notes that the state in Phu Yen district was not able to control forest use as effectively as the customary management systems of the past. The elimination of indigenous

\footnotetext{
${ }^{8}$ Although there was an increase in planted forests, cover only rose by 6.39 per cent for $2000-05$, and 4.68 per cent for $2005-10$.
} 
institutions combined with economic liberalization has thus aggravated deforestation since the 1980s. ${ }^{9}$

Nowadays, regulations are more strictly enforced by the commune. The richest forest land has been set aside as protected forest, where local people have limited access rights (focus groups, Tuong Ha and Tuong Tien, April 2010). Households have also been given 2 ha each of upland to develop into 'managed' forests, although the quality of the land and productivity of forestry is poor and requires a capital investment beyond the reach of poorer households.

The massive reduction in primary forest cover, combined with strict regulations on the use of remaining forest, has made the shifting cultivation of the past virtually impossible. Land can no longer be left fallow for long periods, reducing natural fertility, while deforestation has led to significant soil run-off. Many of the H'mong community from above Tuong Ha have migrated to Moc Chau district to locate better agricultural land (household interview, Dan-1, April 2010). Many of the local Thai and Muong, however, have become more dependent upon fishing, which offers more secure returns than agriculture, taking loans to invest in boats and equipment. Paradoxically, at the same time, increased soil erosion in the watershed has undermined the quality of the main remaining common property ecosystem, the reservoir. Local people reported in interviews that post-rain run-off from surrounding deforested hillsides has caused the water which was once 'clear' to become cloudy, increasing water turbidity and undermining fish reproduction. Although the intensification of fishing has brought short-term benefits and boosted the local economy, there is a perception that stocks have been falling, with certain species such as eel, turtles and a cat fish known as cá quât, being rarely seen nowadays. Lift nets, which catch a large number of immature fish, are viewed as particularly destructive (fieldnotes, April 2010). This fall in stocks is understandable given that the reservoir remains virtually an open access resource: there are limited state-enforced rules regulating fishing and no restrictions on households from outside the area coming to fish in the reservoir. ${ }^{10}$

\footnotetext{
${ }^{9}$ In Hoàng's (2011) study from further upstream in the Phu Yen valley, deforestation is primarily due to the demand for high-value timber produce in the lowlands rather than demand for land to grow cash crops, although the process of rising cash needs amongst the local population is the same.

${ }^{10}$ There was also no evidence of the emergence of indigenous institutions regulating fishing similar to those present for the use of common lands in the past. This is unsurprising: there were large numbers of fishers coming from a wide area, making it difficult to develop or enforce rules (see Ostrom, 1990).
} 
While it is evident in Phu Yen that articulations between a peasant economy and capitalism are undermining common property ecosystems, the growing inequalities in such regions which are yet to experience full capitalist development, add a new dimension. As Sikor and Nguyen (2007) argue with reference to Vietnam's Central Highlands, whether or not one can benefit from environmental resources is often dependent upon one's political and economic resources. This is an important issue in the context of environmental decline. The one ecosystem which retains its use value in Phu Yen is the reservoir. However, as the aquatic natural resource base declines, benefits are increasingly cornered by the wealthier households with access to capital, despite the fact that poorer households are arguably more dependent upon the reservoir. Utilizing their income from other capital-intensive activities such as aquaculture and livestock raising, richer households can afford to invest in equipment such as motorized boats and larger seine nets.

Only three households categorized as 'poor' in the wealth ranking own more expensive wood or metal boats, as opposed to seven households in the 'medium' category and seven from the 'rich' category. Poorer households are more likely to fish using small boats and simpler technologies such as shrimp traps. The boats used to lay and collect traps can be built for around 300,000 VND (US\$ 15), while traps are often given in advance by intermediaries who later buy the catch, reducing the fisher's bargaining power at the time of sale. For such households, fishing can only be done for six months a year when the water level is high in the vicinity of the village. Their wealthier counterparts, however, can travel to distant parts of the reservoir all year round to locate the richest stocks of fish, something particularly important given the fragile natural resource base. It is important to note that these wealthier fisher and farmers cannot yet be considered a 'capitalist' class. There is little evidence of significant accumulation of wealth and much labour is still carried out by the household members themselves, suggesting the peasant economic formation is not in decline. Nevertheless, the process of differentiation in access to natural resources is intricately tied to the emerging articulations with the capitalist economy of the lowlands which provides new (albeit limited) opportunities for wealth generation.

\section{Natural Resource Extraction, 'Conservation' and Enclosure}


The third process through which communities are marginalized from common property ecosystems is via conservation-driven enclosure, a process which occurs not due to ecological or internal economic stress, but due to externally imposed intervention on a political level. It has already been shown that in Buxa, India, the colonial and post-colonial state directly restricted access to forests to protect reserves of timber and create a captive labour force. The enclosure of common property resources for commercial exploitation is widespread under neoliberalism in post-colonial economies driven by natural resource extraction (see e.g., Nguiffo, 1998). This further undermines fragile ecosystems as short-term profit outweighs considerations of the long-term environmental impact. It can also worsen degradation by users themselves. Like in Phu Yen, over-use by marginalized communities occurs on land which has not yet been privatized (Ho, 2006; Johnson, 2004; Parayil and Tong, 1998; Rangarajan and Shahbuddin, 2006).

In Buxa, the process of enclosure has taken on a more complex character in recent years as 'conservation' has taken precedence over resource extraction. While essential for protecting biodiversity, conservation is also instrumental to capitalist growth (Brockington and Duffy, 2010). On one level, conservation has been argued to have 'ideological' power, associated with the commoditised images of nature and romanticised wilderness (Brockington and Duffy, 2010). This ideology can be connected to expanding sectors under neoliberal globalization, such as tourism (Duffy and Moore, 2010). On another level, conservation offers more explicit material gains to capital through, for example, the profits in protecting genetic resources (Brockington and Duffy, 2010). Furthermore, restrictions on livelihoods can provide new sources of surplus through creating a captive labour force no longer able to meet their subsistence needs through forest-based activities alone (Sodikoff, 2007, 2009) — a process already established in Buxa by forest protection laws with an extractive orientation.

The use of conservation as a justification for controlling access to ecosystems became widespread only in the early 1970s (Rangarajan and Shahbuddin, 2006). Buxa was declared a Tiger Reserve in the 1980s, paralleling clampdowns on forest use across West Bengal. In the whole state, 5,032 people were arrested collecting firewood and non-timber forest products in 1996-7 (Banerjee et al., 2010). The dolomite mine was closed in the 1980s, and the railway which once served it fell into disrepair. Today, the forest department is seeking to evict inhabitants from many forest villages, particularly from 'enclave villages' such as Jayanti, 
deep in the forest (ibid.). Across India, 2,904 families have been displaced since the inception of Project Tiger in the 1970s (Kabra, 2009).

Forest dwellers continued to reside in the newly designated tiger reserve, although severe restrictions on access to forest resources remained in place, and there was a deep sense of mistrust towards the forest authorities and a resentment of its policies. The sentiments were echoed during a focus group discussion in Buxa cluster: 'we love nature, we love the forest, but we do not need the Forest Department' — a statement which drew a round of applause.

This could indicate a changed character of capitalist infiltration. While there has been a decline in revenue-generating forestry operations, enclosure for conservation has still served the interests of the capitalist sector. The subjugation of older modes of production to capitalism in the context of ecosystem enclosure are very similar to the colonial and postcolonial periods which were driven by efficient resource exploitation. On the one hand, households displaced from the reserve are still likely to create an easily exploited labour force with limited resources (Kabra, 2009). On the other hand, for those who remain in the forest and on its fringe, the stricter forest laws reproduce the economic insecurities which have been drawing households into the labour force since colonial times.

In the context of an aggressive conservation agenda, it is only in the very remote cluster of Adma that forest-based livelihoods are nearly sufficient for households' subsistence needs, and continue to follow long-established patterns. Livelihoods include limited cultivation, herding in the forest and the raising of livestock in temporary pastures. In many ways its remoteness from state control allows the pre-capitalist mode of production to persist here with a level of autonomy not present elsewhere. In the main villages of Buxa Fort and Jayanti cluster, forest department restrictions mean that pre-capitalist natural resource based livelihoods persist, but they are rarely enough on their own for subsistence, and labouring remains a primary source of income.

While the move towards a conservation agenda has reportedly caused a decline in forestbased wage labour, it is evident in Figure 7 that households have simply diverted their labour to new sectors of the capitalist economy, particularly the burgeoning construction sector in 
growing urban centres. There is today a considerable amount of seasonal out-migration ${ }^{11}$ to cities such as Kolkata, Siliguri and Delhi, while some of the Drukpa community who are familiar with the language and culture regularly migrate to Bhutan for construction work, although they lack citizenship papers so can only secure menial employment. 'Other labour' in Figure 7 includes jobs associated with the conservation enterprise itself: portering goods for forest officials and maintaining trails for forest guards (Sodikoff, 2007). This labour is partially subsidized by agriculture, livestock rearing and gathering, which perhaps explains why some forest-based livelihoods are tolerated.

[Figure 7 about here]

Resource extraction by more powerful actors is still allowed in the reserve, a process also observed in other protected regions of India (Rangarajan and Shahbuddin, 2006). The collection of rocks from the river in Jayanti is one example, and many of the local people labour for urban contractors. In fact, across India between 1980 and 2003, the government approved forest land use 'diversion' of an area of 7,903 ha of forest in which 5,888 ha were allocated for boulder collection (Banerjee et al., 2010). Tourism development also has increased considerably over the last decade, absorbing some local labour in the numerous guesthouses along the river bank in Jayanti, a site of natural beauty and a prime spot for viewing animals. There are contradictory processes at play with regards to these two sectors. Rock collecting had previously been banned, but was permitted again in recent years, while the government has recently sought to restrict tourist access to the reserve, despite Buxa being a key attraction in tourism promotional campaigns for the Dooars. This suggests that there are different interests within the state which promote 'conservation', tourism and the more traditional colonial agenda of resource extraction.

This case study illustrates that as long as the state tolerates the presence of forest dwellers following highly restricted livelihood patterns, a supply of cheap labour for the plantation and forestry-based capitalist sector in North Bengal region will continue to be provided. The forest is converted into a 'partial' common property resource, whereby some level of use is

\footnotetext{
${ }^{11}$ Note that most seasonal migrant labour is classified as 'wage work' in Figure 12. [presume you mean Figure 7. The figure actually uses the term 'wage labour'] 'Income from family members living outside' generally refers to remittances from longer term migrants.
} 
tolerated, but only to the extent that communities are still obliged to enter the labour force to meet the remainder of their subsistence needs. By retaining a limited pre-capitalist mode of production grounded in small-scale agriculture, fishing and non-timber resource harvesting, labour is 'subsidized' and wages can remain low. Sodikoff (2007) suggests that conservation involves an interesting contradictory process, whereby forest-based livelihoods continue to be tolerated in reserve forests, both subsidizing labour power and increasing the subjective human 'threat' to biodiversity, which in turn continues to increase its value as a conservation hot spot.

\section{CONCLUSION}

This article has identified three inter-connected and complex processes of capitalist expansion through which access to common property ecosystems has been undermined. The decline of these resources has been shown to occur on an ecological level due to environmental degradation; on an economic level due to livelihood insecurity, debt and rising cash needs; and on a political level through unequal power relations, coercive measures of the state and enclosure. The character and relative importance of these three processes in mediating the nature-society nexus in each site is intricately connected to the unique ways in which capitalism interacts with older economic formations.

In Shaoguan, China, the decline in common property resources is primarily due to ecological change in the context of competition with large-scale resource users in this rapidly developing capitalist economy — although on a political level, power relations which reduce the voice of fishers in river basin planning remain important. The decline in common property resources parallels the decline in older economic formations and the gradual assimilation of fishers into the urban working class. In Phu Yen, Vietnam, the degradation of the ecosystem has also been a central process through which common property ecosystems have been in decline. However, degradation here is by small-scale users themselves. This is connected to internal economic stress brought about when the capitalism of the urban centres interacts with the older economic formations of the uplands, increasing local cash needs and demand from lowland markets for fish and cash crops. The end result is a decline in the natural resource base and a reduction in the utility of ecosystems to all but a few 
'accumulating' households. In Buxa, India, it has not been environmental degradation which has undermined common property dependent livelihoods but direct exclusion on a political level through state-sanctioned enclosure. Enclosure emerged first through the need for the state to corner natural resources to feed the capitalist primary sector of the region. More recently exclusion has been driven by a conservation agenda, retaining the forest as a tourist resource, while also facilitating the creation of a cheap labour force, subsidized in part by more restricted forest-based livelihoods.

The three case studies have illustrated that global processes like capitalism take specific local forms related to national and regional socio-economic and political systems as well as to the specific historical characteristics of a region. The three cases do, however, clearly demonstrate a shared contemporary process: the decline of common property ecosystems with market globalization. Whilst recognizing the different trajectories of capitalist development, it is evident that wholesale waged labour and subordination to market or commercial imperatives have resulted in fundamental changes to common property resources.

\section{Acknowledgements}

We would like to thank the European Commission for funding the HighARCS (Highland Aquatic Resources Conservation and Sustainable Development) research, and the local partners and their research teams, in particular: Luo Shiming, Liu Yiming, Cai Kunzheng and Cai Jian at South China Agricultural University, Guangdong, China; Rajeshwar Mishra, Dhananjay Ray, Subrata Majumdar and Chandan Ray at the Centre for the Development of Human Initiatives, Jalpaiguri, India; Nitai Kundu and Mausumi Pal at the Centre for Environmental Management and Participatory Design, West Bengal; Nguyen Thi Dieu Phuong, Nguyen Thi Hanh Tien, Do Van Thinh, Nguyen Hai Dang and Nguyen Thi Trang at the Research Institute for Aquaculture No.1, Hanoi; Søren Lund, International Development and Participatory Environmental Planning at the University of Roskilde, Denmark; Mary Ann Bimbao from FishBase, Manila; Kevin Smith, International Union for Conservation of Nature and Stuart Bunting, the project coordinator at the Centre for Environment and Society, University of Essex. The research leading to this article has received funding from the 
European Community's Seventh Framework Programme FP7-El\rv-2007-1 under grant agreement No. 213015. This publication reflects the authors' views, and the European Community is not liable for any use that may be made of the information contained herein. We also thank the anonymous reviewers whose constructive comments enabled us to clarify some of our arguments. 


\section{REFERENCES}

Agarwal, B. (1998) 'Environmental Management, Equity and Ecofeminism: Debating India's Experience', Journal of Peasant Studies 25(4): 55-95.

Akram-Lodhi, A.H. (2005) 'Vietnam’s Agriculture: Process of Rich Peasant Accumulation and Mechanisms of Social Differentiation', Journal of Agrarian Change 5(1): 73116.

Akram-Lodhi, A.H. (2007) 'Land, Markets and Neo-liberal Enclosure: An Agrarian Political Economy Perspective', Third World Quarterly 28(8): 1437-56.

Akram-Lodhi, A.H. (2008) '(Re) imagining Agrarian Relations? The World Development Report 2008: Agriculture for Development', Development and Change 39(6): 1145 61.

Althusser, L. and E. Balibar (1968) Reading Capital. London: Redwood Burn Ltd.

Banerjee, A., S. Ghosh and O. Springate-Baginski (2010) 'The Creation of West Bengal's Forest Underclass: An Historical Institutional Analysis of Forest Rights Deprivations'. IPPG Discussion Paper No. 51. Manchester: University of Manchester, Research Programme Consortium for Improving Institutions for Pro-Poor Growth.

Beck, T. and M.G. Ghosh (2000) 'Common Property Resources and the Poor: Findings from West Bengal', Economic and Political Weekly 35(3): 147-53.

Bernstein, H. (1977) 'Notes on Capital and Peasantry', Review of African Political Economy 10(issue?): 60-73.

Bernstein, H. (2003) 'Farewells to the Peasantry', Transformation 52(issue?): 1-19.

Bhowmik, S.K. (1988) 'Development Problems of Chotanagpur Tribals in North Bengal', in B.B. Mandal Sachchidananda, K.K. Verma and R.P. Sinha (eds) Tradition and Development, pp. 63-94. New Delhi: Concept Publishing Company.

Blaikie, P. and H. Brookfield (1987) Land Degradation and Society, New York: Methuen.

Brandt, L. and B. Sands (1990) 'Beyond Malthus and Ricardo: Economic Growth, Land Concentration, and Income Distribution in Early Twentieth Century China', The Journal of Economic History 50(4): 807-27.

Brockington, D. and R. Duffy (2010) 'Capitalism and Conservation: The Production and Reproduction of Biodiversity Conservation', Antipode 42(3): 469-484 
Buoye, T. (1993) 'From Patrimony to Commodity: Changing Concepts of Land and Social Conflict in Guangdong Province during the Qianlong Reign (1736-1795)', Late Imperial China 14(2): 33-59.

Chaudhuri, A.K. (1995) Enclaves in a Peasant Society: Political Economy of Tea in Western Dooars in Northern Bengal. New Delhi: People's Publishing House.

Cleaver, F. (1999) 'Paradoxes of Participation: Questioning Participatory Approaches to Development', Journal of International Development 11(4): 597-612.

Cleaver, F. (2001) 'Institutions, Agency and the Limitations of Participatory Approaches to Development', in B. Cooke and U. Kothari (eds) Participation: The New Tyranny, 3655. London and New York: Zed Books.

Dao, M.Q. (1993) 'History of Land Tenure in Pre-1954 Vietnam', Journal of Contemporary Asia 23(1): 84-92.

Dasgupta, P. (2008) 'Common Property Resources: Economic Analytics', in R. Ghate, N. Jodha and P. Mukhopadhyay (ed.) Promise, Trust and Evolution: Managing the Commons of South Asia, 19-51, Oxford: Oxford University Press.

Dey, C. (1997) 'Women, Forest Products and Protected Areas: A Case Study of Jaldapara Wildlife Sanctury, West Bengal, India', in K. Ghimire and M.P. Pimbert (eds) Social Change and Conservation, pp. 131-57. London: Earthscan.

Do, V.T., T.H.T. Nguyen, T.T. Nguyen, T.D.P. Nguyen, H.D. Nguyen and F. Sugden (2011) 'Report on Livelihoods Dependent on Highland Aquatic Resources in Northern Vietnam'. Report compiled for EC funded project, HighARCS. Hanoi: Research Institute for Aquaculture.

Duffy, R. and L. Moore (2010) 'Neoliberalising Nature? Elephant-back Tourism in Thailand and Botswana', Antipode 42(3): 742-66.

Dupré, G. and P.P. Rey (1979) 'Reflections on the Relevance of a Theory of the History of Exchange', in D. Seddon and H. Lackner (eds) Relations of Production: Marxist Approaches to Economic Anthropology, pp. 171-208. London: Frank Cass.

Eyferth, J., P. Ho and E. Vermeer (2003) 'Introduction: The Opening-up of China's Countryside', Journal of Peasant Studies 30(3): 1-17.

FAO (2010) Global Forest Resources Assessment 2010. Rome: Food and Agriculture Organization of the UN.

Feuerwerker, A. (1984) 'The State and the Economy in Late Imperial China', Theory and Society 13(3): 297-326. 
Folving, R. and H. Christensen (2007) 'Farming System Changes in the Vietnamese Uplands:

Using Fallow Length and Farmers' Adoption of Sloping Agricultural Land

Technologies as Indicators of Environmental Sustainability', Danish Journal of Geography 107(1): 43-58.

Geschiere, P. and R. Raatgever (1985) 'Introduction', in W. van Binsbergen and P. Geshiere (eds) Old Modes of Production and Capitalist Encroachment, pp. 1-38. Leiden: Kegan Paul International.

Grunning, J.F. (2007) [1911] Eastern Bengal and Assam District Gazetteers: Jalpaiguri.

Siliguri: N.L. Publishers.

Hall, D., P. Hirsch and T. Murray Li (2011) Powers of Exclusion: Land Dilemmas in Southeast Asia. Honolulu, HI: University of Hawai'i Press.

Han, L.X., W. Li, Y.J. Lu and S.P. Mo (2005) 'The Influence of Sand Mining on the Water Dynamic and Environment of the East River', Journal of Hohai University: Natural Sciences 33(issue?): 123-6.

Harvey, D. (2003) The New Imperialism. New York: Oxford University Press.

Ho, P. (2006) 'Credibility of Institutions: Forestry, Social Conflict and Titling in China', Land Use Policy 23(4): 588-603.

Hoàng, C. (2011) “"Forest Thieves”: State Resource Policies, Market Forces, Struggles over Livelihood and Meanings of Nature in a Northwestern Valley of Vietnam', in T. Sikor, P.T. Nghiem, J. Sowerwine and J. Romm (eds) Opening Boundaries: Upland Transformations in Vietnam, 92-114, Singapore: NUS Press Pte Ltd.

Hue, L.V. (2008) 'Gender, Doi Moi and Coastal Resource Management in the Red River Delta, Vietnam', in B.P. Resurreccion and R. Elmhirst (eds) Gender and Natural Resource Management: Livelihoods, Mobility and Interventions, 23-42, London: Earthscan.

Hue, L.V. and S. Scott (2007) 'Coastal Livelihood Transitions: Socio-Economic

Consequences of Changing Mangrove Forest Management and Land Allocation in a Commune of Central Vietnam', Geographical Research 46(1): 62-73.

de Janvry, A. (1981) The Agrarian Question and Reformism in Latin America. Baltimore, MD: Johns Hopkins University Press.

Jiang, B., Q. Wang, M. Gao and S.Luo (2011) 'Institutions, Policies and Conflicts Related to Sustainable Use and Protection of Aquatic Resources in Beijiang River Watershed, 
China'. Report Compiled for EC funded project: HighARCS. Guangzhou: South China Agricultural University.

Johnson, C. (2004) 'Uncommon Ground: The "Poverty of History" in Common Property

Discourse', Development and Change 35(3): 407-34.

Kabra, C. (2009) 'Conservation-induced Displacement: A Comparative Study of Two Indian Protected Areas', Conservation and Society 7(4): 249-67.

Kerkvliet, B.J. (2006) 'Agricultural Land in Vietnam: Markets Tempered by Family, Community and Socialist Practices', Journal of Agrarian Change 6(3): 285-305.

Liu, Y., C. Shang, F. Sugden, S. Luo, F. Chen, W. Wang, B. Jiang, M. Gao, H. Li and Y. Ye (2011) 'Report on Livelihoods Dependent upon Highland Aquatic Resources: A Case Study at Shaoguan, China'. Report compiled for EC funded project: HighARCS. Guangzhou: South China Agricultural University.

Luo, S., K. Cai, H. Zhou, K. Cui, L. Gan, J. Fu, X. Zhuang, X. Tong, J. Zhang, Y. Ye, H. Li and H. He (2011) 'Report on Highland Aquatic Ecosystem Services and Biodiversity Values in Beijiang River, China'. Report compiled for EC funded project:

HighARCS. Guangzhou: South China Agricultural University.

Luong, H.V. and J. Unger (1998) 'Wealth, Power, and Poverty in the Transition to Market Economies: The Process of Socio-economic Differentiation in Rural China and Northern Vietnam', China Journal 40(issue?): 61-93.

Luttrell, C. (2006) 'Adapting to Aquaculture in Vietnam: Securing Liverlihoods in a Context of Change in Two Coastal Communities', in C.T. Hoanh, T.P. Tuong, J.W. Gowing and B. Hardy (eds) Environment and Livelihoods in Tropical Coastal Zones: Managing Agriculture-Fishery-Aquaculture Conflicts, 17-29, Abingdon, Oxon: CABI.

Marx, K. (1932) Economic and Philosophic Manuscripts. Moscow: Progress Publishers. Meillassoux, C. (1973) 'The Social Organisation of the Peasantry: The Economic Basis of Kinship', Journal of Peasant Studies 1(1): 81-90.

Nguiffo, S. (1998) 'In Defence of the Commons: Forest Battles in Southern Cameroon', in M. Goldman (ed.) Privatizing Nature: Political Struggles for the Global Commons, 102-119, London: Pluto Press.

Ostrom, E. (1990) Governing the Commons: The Evolution of Institutions for Collective Action. Cambridge: Cambridge University Press. 
Oya, C. (2001) 'Large- and Middle-scale Farmers in the Groundnut Sector in Senegal in the Context of Liberalization and Structural Adjustment', Journal of Agrarian Change 1(1): $124-163$

Parayil, G. and F. Tong (1998) 'Pasture-led to Logging-led Deforestation: The Dynamics of Socio-environmental Change in the Brazilian Amazon', Global Environmental Change 8(1): 63-79.

Patnaik, U. (2007) 'Imperialism, Contemporary Disorder in World Resources and Food Security, with reference to the Indian Experience'. Paper presented at the Fifth International Conference of Critical Geography, Tata Institute of Social Sciences, Mumbai (3-7 December).

Platteau, J.P. and A. Abraham (2002) 'Participatory Development in the Presence of Endogenous Community Imperfections', Journal of Development Studies 39(2): 104 36.

Punch, S. and F. Sugden (2013) 'Work, Education and Out-migration among

Children and Youth in Upland Asia: Changing Patterns of Labour and Ecological Knowledge in an Era of Globalisation', Local Environment 18(3): 255-70.

Qian, Y.Q. (2004) 'Influence of Uncontrolled Sand Mining in the Pearl River Delta and the Management Measures', Journal of People's Pearl River 2 (issue?): 44-47.

Raatgever, R. (1985) 'Analytic Tools, Intellectual Weapons: The Discussions among French Marxist Anthropologists about the Identification of Modes of Production in Africa', in W. van Binsbergen and P. Geshiere (eds) Old Modes of Production and Capitalist Encroachment: Anthropological Explorations in Africa, pp. 290-327. Leiden: Kegan Paul International.

Rangarajan, M. and G. Shahbuddin (2006) 'Displacement and Relocation from Protected Areas: Towards a Biological and Historical Synthesis', Conservation and Society 4(3): 359-78.

Ray, S. (2002) Transformations on the Bengal Frontier: Jalpaiguri, 1765-1948. London: Routledge-Curzon.

Schwartz, B. (1954) 'A Marxist Controversy on China', The Far Eastern Quarterly 13(2): $143-54$.

Sikor, T. (2001a) Agrarian Differentiation in Post-Socialist Societies. Development and Change,32 (5): 923-949 
Sikor, T. (2001b) 'Agrarian Differentiation in Post-Socialist Societies: Evidence from Three Upland Villages in North-Western Vietnam', Development and Change 32(5): $923-$ 49.

Sikor, T. (2004) 'Conflicting Concepts: Contested Land Relations in North-western Vietnam', Conservation and Society 2(1): 75-95.

Sikor, T. and T.Q. Nguyen (2007) 'Why May Forest Devolution Not Benefit the Rural Poor? Forest Entitlements in Vietnam's Central Highlands', World Development 35(11): $2010-25$.

Sikor, T. and D. O'Rourke (1996) 'A Tiger in Search of a New Path: The Economic and Environmental Dynamics of Reform in Vietnam', Asian Survey 36(6): 601-17.

Sikor, T. and D.M. Truong (2002) 'Agricultural Policy and Land Use Change in a Black Thai Commune of Northern Vietnam: 1952-1997', Mountain Research and Development 22(3): 248-55. [See above: Sikor 2002]

Sikor, T. and P.T.T. Vi (2005) 'The Dynamics of Commoditization in a Vietnamese Uplands Village: 1980-2000', Journal of Agrarian Change 5(3): 405-28.

Sodikoff, G. (2007) ‘An Exceptional Strike: A Micro-history of "People versus Park” in Madagascar', Journal of Political Ecology 14(issue?): 10-33.

Sodikoff, G. (2009) 'The Low Wage Conservationist: Biodiversity and Perversities of Value in Madagascar', American Anthropologist 111(4): 443-55.

Sugden, F. (2010) 'Divergent State Formations and Patterns of Migration in the Nepal-India Borderlands'. Paper presented at conference, Culture and Politics of South Asian Migration, Delhi University (22-24 November).

Sugden, F. (2013) 'Pre-capitalist Reproduction on the Nepal Terai: Semi-feudal Agriculture in an Era of Globalisation', Journal of Contemporary Asia 43(3): 519-45.

Wade, R. (1987) 'The Management of Common Property Resources: Collective Action as an Alternative to Privatisation or State Regulation', Cambridge Journal of Economics 11(issue?): 95-106.

World Bank and SEPA (2007) 'Cost of Pollution in China: Economic Estimates of Physical Challenges'. World Bank and State Environmental Protection Administration, preliminary presentation of results, Beijing (2 and 27 March).

Yan, Y. (1992) 'The Impact of Rural Reform on Economic and Social Stratification in a Chinese Village', The Australian Journal of Chinese Affairs 27(issue?): 1-23 


\section{Author bio sketch..}

Fraser Sugden (International Water Management Institute, Jamsikhel, Lalitpur, Nepal; email: F.Sugden@cgiar.org)

Samantha Punch (School of Applied Social Science, University of Stirling, Stirling, FK9 4LA; e-mail: s.v.punch@stir.ac.uk) 
Figure 1: Location Map of Shaoguan field site

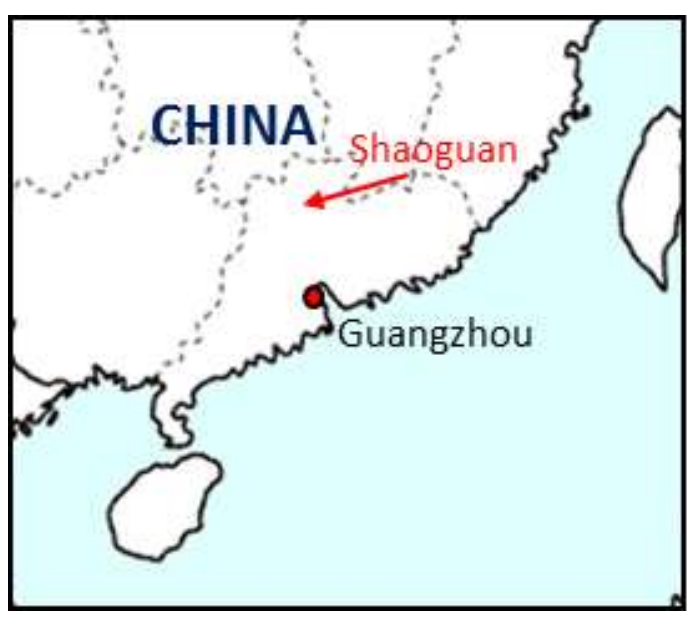

Figure 2: Average cash income by households over last month in Shaoguan sample in Chinese Renminbi (Rmb) (source: survey)

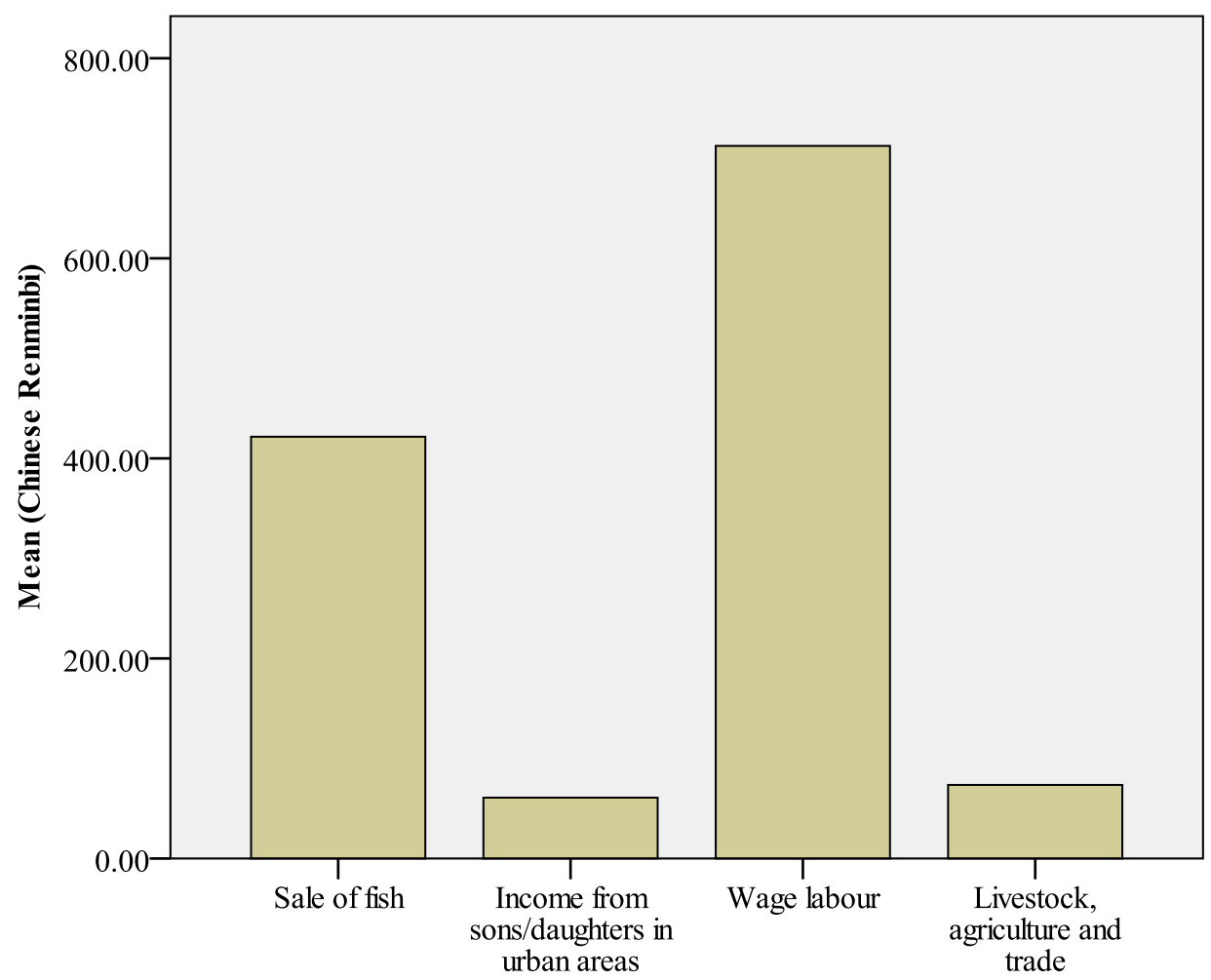

Figure 3: Location map of Phu Yen field site

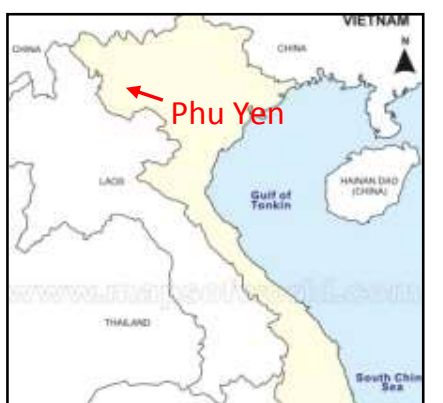




\section{VIETNAM}

Figure 4: Cash income over last month by Phu Yen sampled households in Vietnamese Dong (VND) (source: survey)

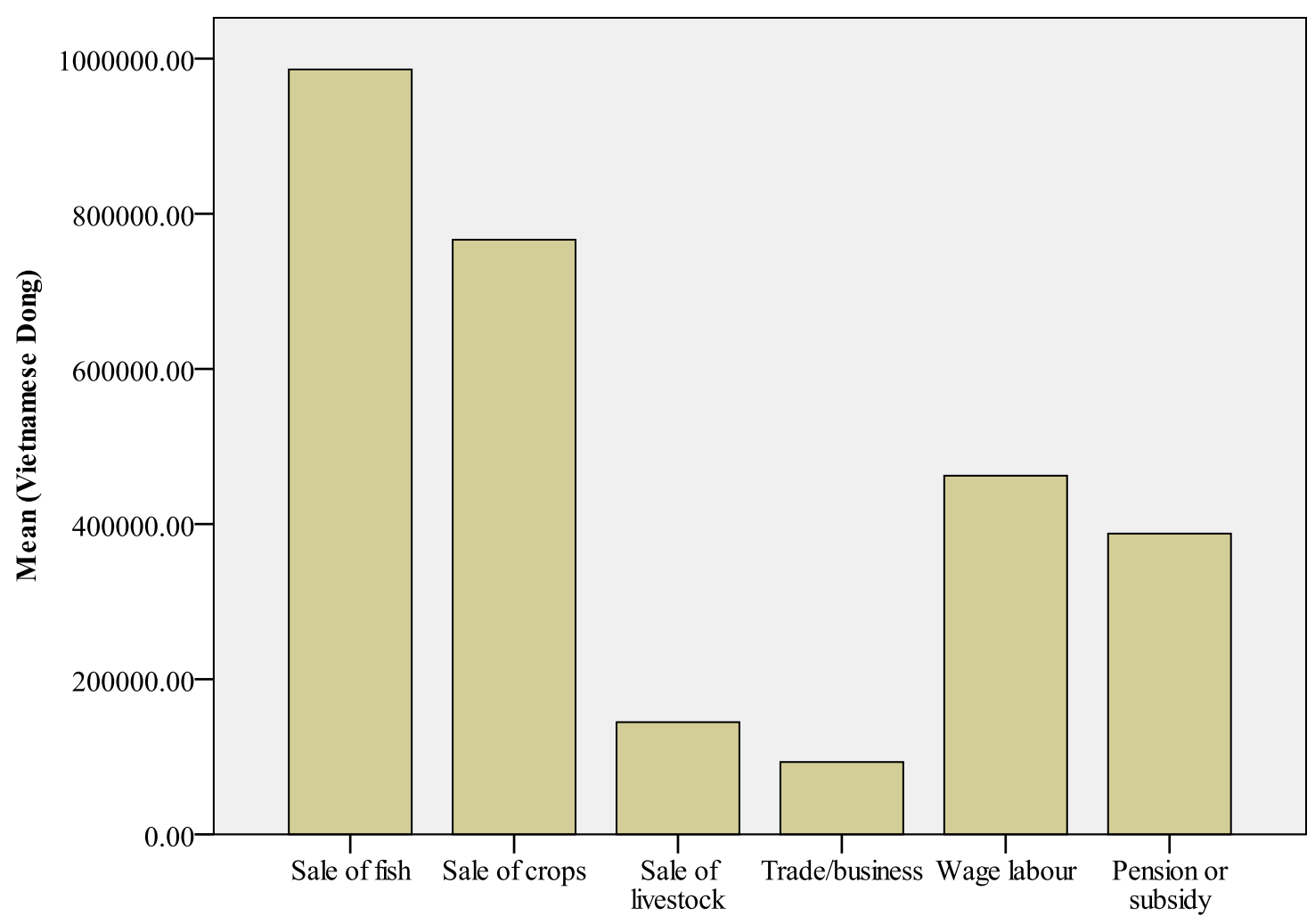

Figure 5: Average expenditure over last year by Phu Yen sampled households in Vietnamese Dong (VND) (source: survey) 


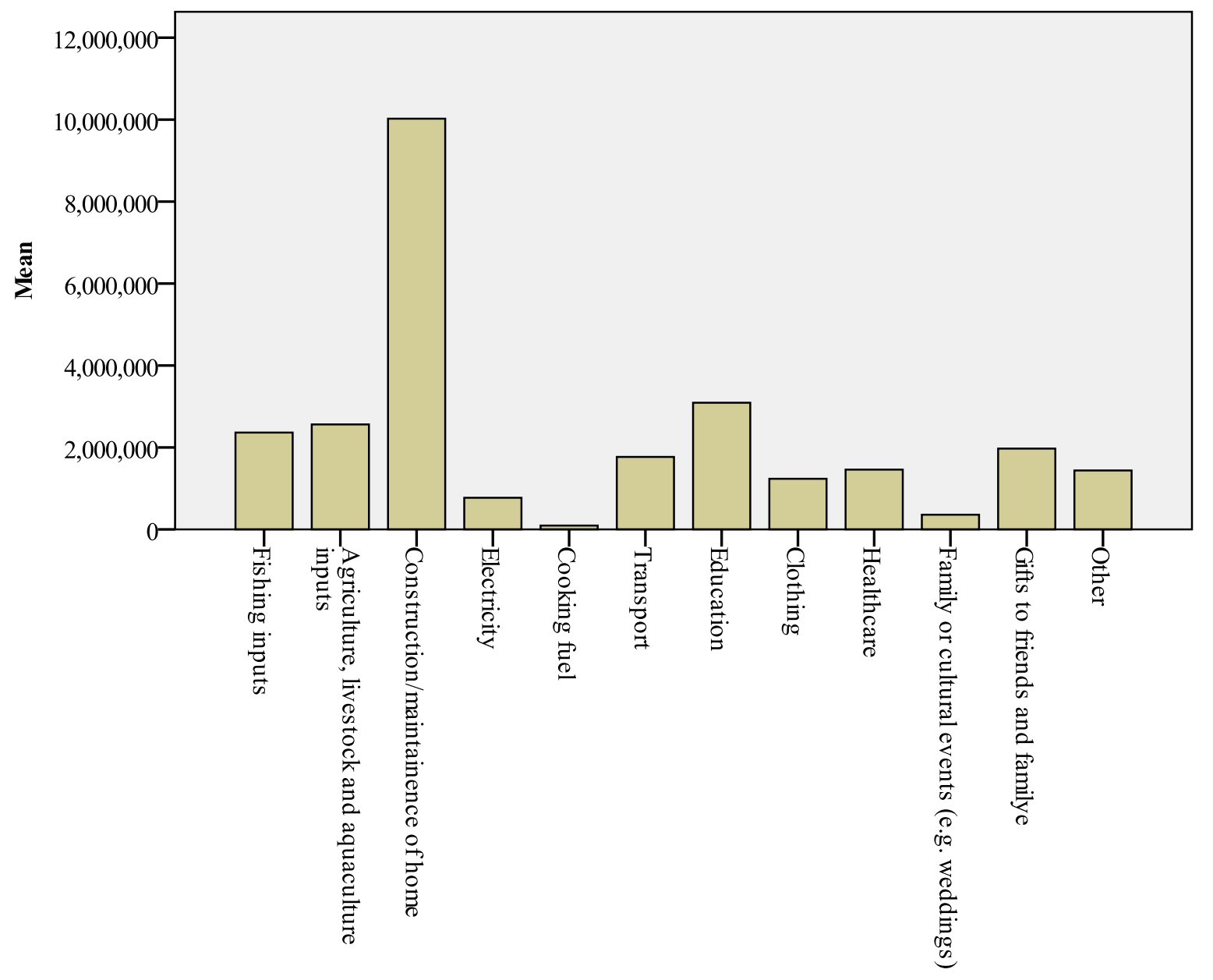


Figure 6: Location map of Buxa field site

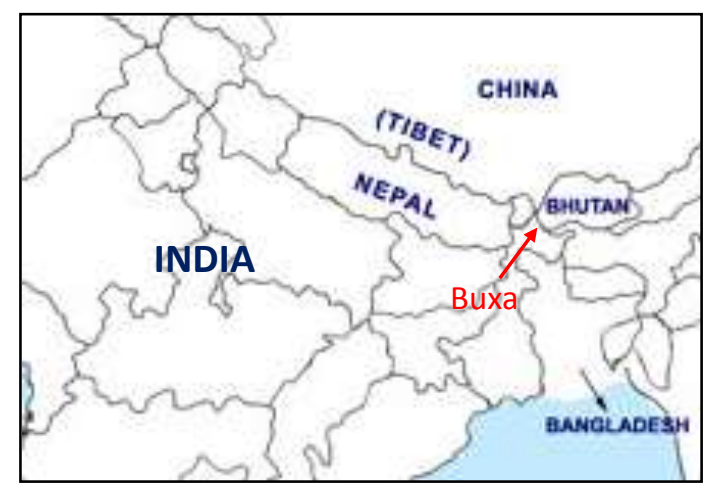

Figure 7: Average cash income by households over last month in Buxa in Indian Rupees (source: survey)

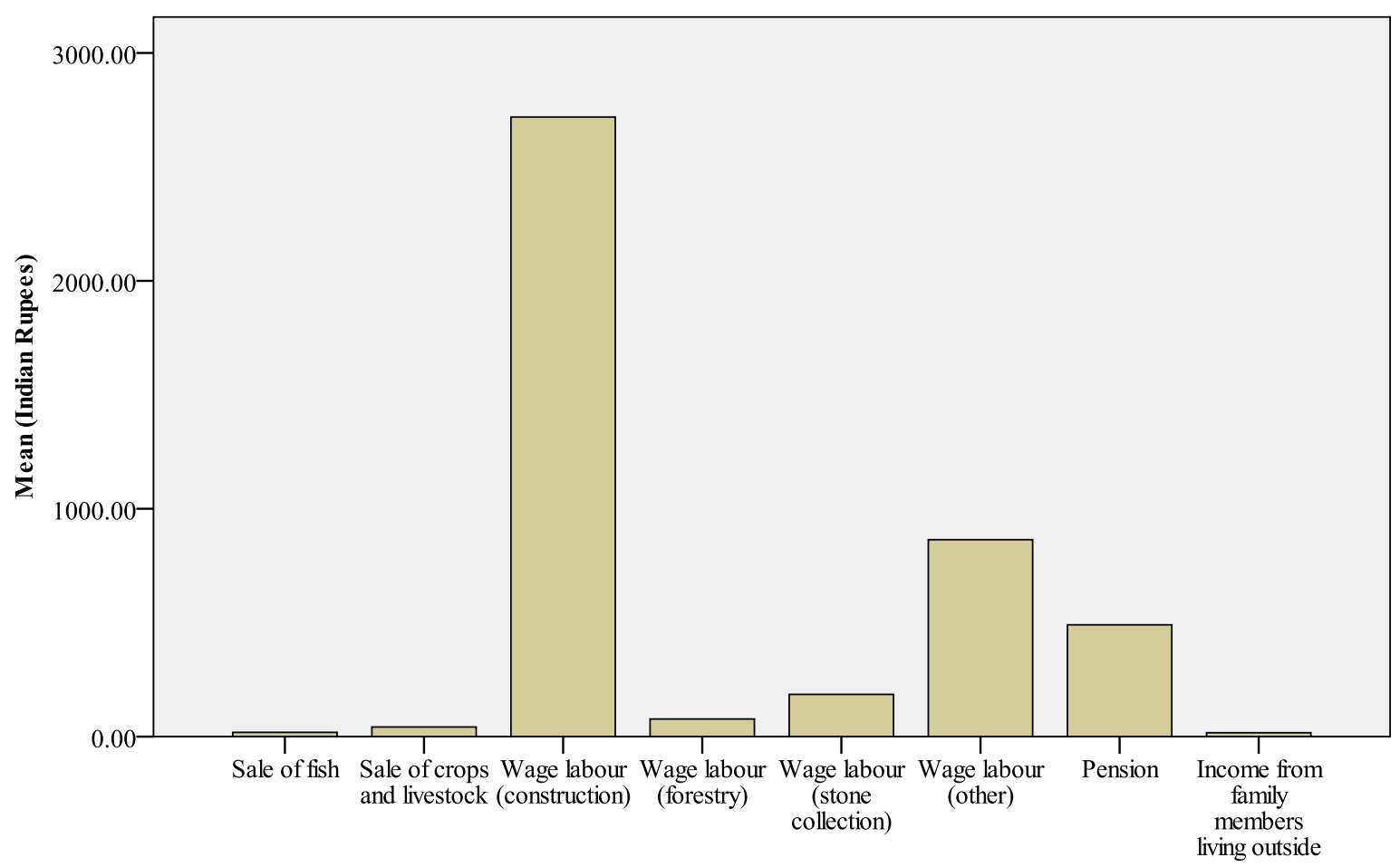

